\title{
REFORMASI HUKUM DALAM RANGKA MEWUJUDKAN KEADILAN BAGI PEREMPUAN: TELAAH FEMINIST JURISPRUDENCE
}

\author{
Aga Natalis \\ Fakultas Hukum, Universitas Semarang \\ Jl. Soekarno-Hatta, Tlogosari, Semarang \\ aganata12@gmail.com
}

\begin{abstract}
The state have to realize legal instruments in order to advance gender justice and women's empowerment, but in reality there are still deviations from these principles, because legal instruments tend to perpetuate male domination of women. The purpose of writing this article is to find out and analyze regarding the concept of justice for women and efforts to realize legal reform through a feminist jurisprudence approach. The concept of justice for women, that the law must guarantee women the right to live in dignity and freedom without fear, which can be realized by applying responsive legal types. The type of responsive law recognizes the existence of legal pluralism which impacts on the wide opportunity for women to participate in the law-making process. Efforts to realize legal reform through a feminist jurisprudence approach begins with the perception that the law is formed based on masculine values, showing a number of limitations or linkages to the reality of social values. Such a law must be reformed in order to realize the justice for women.
\end{abstract}

Keywords: Legal Reform; Justice; Women

\begin{abstract}
Abstrak
Negara harus bertindak untuk mewujudkan instrumen hukum dalam rangka memajukan keadilan gender dan pemberdayaan perempuan, namun pada kenyataannya masih terjadi penyimpangan terhadap prinsip tersebut, karena instrumen hukum cenderung melanggengkan dominasi laki-laki terhadap perempuan. Tujuan penulisan artikel ini adalah untuk mengetahui dan menganalisis mengenai konsep hukum yang berkeadilan bagi perempuan dan upaya mewujudkan reformasi hukum melalui pendekatan feminist jurisprudence. Konsep hukum yang berkeadilan bagi perempuan, bahwa hukum harus menjamin perempuan untuk berhak hidup bermartabat dan bebas tanpa rasa takut, yang dapat terwujud dengan menerapkan tipe hukum responsif. Tipe hukum responsif mengakui adanya pluralisme hukum yang berdampak pada luasnya kesempatan bagi perempuan untuk berpartisipasi dalam proses pembuatan hukum. Upaya mewujudkan reformasi hukum melalui pendekatan feminist jurisprudence dimulai dengan persepsi bahwa hukum yang dibentuk berdasarkan nilai maskulin, menunjukkan sejumlah keterbatasan atau keterkaitan pada realitas nilai-nilai sosial. Hukum yang demikian harus dilakukan reformasi guna mewujudkan hukum yang berkeadilan bagi perempuan.
\end{abstract}

Kata Kunci: Reformasi Hukum; Keadilan; Perempuan

\section{A. Pendahuluan}

Reformasi konstitusi yang berlangsung di Indonesia telah membawa perubahan yang besar terhadap sistem hukum nasional. Perubahan tersebut telah mengarahkan kepada cita- 
cita yang sesuai dengan prinsip-prinsip negara demokrasi konstitusional. Konstitusi adalah panduan dasar untuk mengatur struktur dan tata kelola serta menetapkan prinsip-prinsip hukum yang disepakati. Seiring waktu, reformasi atau penyusunan ulang sebuah konstitusi akan memberikan peluang bagi negara untuk menanamkan atau memperluas ketentuan mengenai keadilan gender, hal ini sejalan dengan Convention on the Elimination of All Forms of Discrimination Against Women (CEDAW) yang menyerukan kepada 'signatory states' untuk mewujudkan prinsip keadilan gender pada konstitusi di negaranya masing-masing.

Negara harus bertindak untuk mewujudkan prinsip tersebut dalam sistem hukum di negaranya masing-masing, termasuk dengan mengubah undang-undang yang diskriminatif untuk kemudian mengadopsi undang-undang yang memajukan keadilan gender dan pemberdayaan perempuan serta memastikan bahwa praktik hukum tersebut memiliki tujuan, yaitu untuk menegakkan hak-hak perempuan. Indonesia telah meratifikasi CEDAW dengan Undang-Undang No. 7 Tahun 1984 tentang Pengesahan Konvensi Mengenai Penghapusan Segala Bentuk Diskriminasi Terhadap Perempuan (Convention on the Elimination of All Forms Discrimination Against Women), tapi dalam praktiknya masih terdapat beberapa instrumen hukum yang bersifat diskriminatif terhadap perempuan, misalnya Pasal 31 Ayat (3) UndangUndang No. 1 Tahun 1974 tentang Perkawinan, yang mengatur bahwa "Suami adalah kepala rumah tangga dan istri adalah ibu rumah tangga". Pasal 31 Ayat (1) dan (2), antara lain menentukan "Suami wajib memberikan segala sesuatu keperluan hidup berumah tangga sesuai dengan kemampuannya, dan istri wajib mengatur rumah tangga sebaik-baiknya". Ketentuan ini menempatkan istri (perempuan) dalam posisi subordinat terhadap suami (laki-laki) ${ }^{1}$.

Ketidakadilan gender juga dipertahankan dalam Hukum Perdata yang didasarkan pada pandangan bahwa perempuan adalah lemah dan harus dilindungi oleh suaminya, seperti termuat dalam beberapa ketentuan dalam Kitab Undang-Undang Hukum Perdata (Burgerlijk Wetboek), misalnya Pasal 105; "Suami mengurus harta kekayaan istri", Pasal 106; "Istri harus tunduk patuh kepada suami” dan Pasal 250-256; "Anak yang dilahirkan dalam perkawinan dapat disangkal oleh suaminya". Beberapa ketentuan tersebut membuktikan kebenaran teori yang dikembangkan oleh Walby tentang patriarki privat, bahwa rumah tangga sebagai tempat berawal kekuasaan atau dominasi laki-laki atas perempuan².

Perbedaan gender sebenarnya tidak akan menimbulkan masalah jika tidak melahirkan ketidakadilan gender. Namun, pada kenyataannya perbedaan gender yang dikembangkan melalui mitos-mitos, sosialisasi, kultur dan kebijakan pemerintah telah melahirkan hukum yang

1 Agnes Widanti, 2005, Hukum Berkeadilan Gender:Aksi Interaksi Kelompok Buruh Perempuan dalam Perubahan Sosial, Jakarta, Penerbit Buku Kompas, hlm 12.

2 Wahyuni Retnowulandari, Budaya Hukum Patriarki versus Feminis: Dalam Penegakan Hukum Di persidangan Kasus Kekerasan Terhadap Perempuan, Jurnal Hukum, Vol. 8, No. 3, Januari 2010, hlm 18. 
tidak adil bagi perempuan. Menurut Mochtar Kusumaatmadja, ketika hukum dikategorikan sebagai kaidah sosial, maka hukum tidak akan terlepas dari nilai (values) yang berlaku, sehingga dapat dikatakan bahwa hukum adalah pencerminan dari standar nilai yang dianut oleh masyarakat ${ }^{3}$. Pada masyarakat patriarki, corak dan implementasi hukum adalah refleksi dari nilai-nilai maskulin, sehingga karakter hukum akan bersifat patriarki dan berpotensi menimbulkan diskriminasi terhadap perempuan, karena hukum yang diberlakukan akan selalu mempertahankan dominasi laki-laki terhadap perempuan melalui hubungan sosial ${ }^{4}$. Corak patriarki dalam bidang ilmu hukum dapat dirasakan pada aliran tradisional hukum, yaitu legal positivism, yang melihat hukum sebagai sebuah realitas yang objektif dan kenyataan adalah tempat berpijak bagi para penegak hukum. Feminist jurisprudence muncul sebagai aliran tandingan yang bertujuan untuk mengkritisi dan melakukan reformasi terhadap tradisi-tradisi tradisional yang sudah mapan dari ilmu hukum seperti legal positivism.

Feminist jurisprudence fokus pada persoalan gender secara konseptual dan perempuan pada praktiknya. Feminist jurisprudence meyakini bahwa tindakan diskriminatif terhadap perempuan dalam bidang hukum disebabkan oleh faktor historis yang berkelanjutan. Melihat kondisi yang demikian, maka para penganut aliran feminist jurisprudence diwajibkan untuk mengupayakan reformasi terhadap tatanan dalam bidang hukum, seperti instrumen-instrumen hukum dan prinsip yang mengatur dari berbagai bidang hukum yang bersifat diskriminatif terhadap perempuan. Reformasi tersebut diharapkan dapat menjadikan hukum bersifat responsif dan menceriminkan perspektif perempuan. Dari permasalahan di atas, menjadikan penulis terinspirasi untuk menciptakan sebuah artikel yang berjudul "Reformasi Hukum Dalam Rangka Mewujudkan Keadilan Bagi Perempuan”. Adapun permasalahan yang menjadi fokus pembahasan dalam artikel ini adalah tentang bagaimana konsep hukum yang berkeadilan bagi perempuan? dan bagaimana upaya mewujudkan reformasi hukum melalui pendekatan feminist jurisprudence? Tujuan penulisan artikel ini adalah untuk mengetahui dan menganalisis mengenai konsep hukum yang berkeadilan bagi perempuan dan upaya mewujudkan reformasi hukum melalui pendekatan feminist jurisprudence.

\section{B. Pembahasan}

\section{Konsep Hukum yang Berkeadilan Bagi Perempuan}

Keadilan gender adalah perwujudan dari Hak Asasi Manusia (HAM), bahwa hukum harus menjamin perempuan untuk berhak hidup bermartabat dan bebas tanpa rasa takut. Keadilan

3 Muhaimin, Penerapan Asas Oportunitas oleh Kejaksaan Agung Bertentangan dengan Asas Legalitas dan Rule of Law, Jurnal Penelitian Hukum De Jure, Vol. 17, No. 1, Maret 2017, hlm 117.

4 Ica Wulansari, Dominasi Maskulin versus Kesetaraan Gender, Jurnal Mozaik, Vol. 13, No. 1, JanuariJuni 2013, hlm 40. 
gender sangat diperlukan untuk pembangunan, pengurangan kemiskinan, dan mencapai kemajuan kehidupan manusia. Selama berabad-abad, kehidupan manusia sudah mengalami kemajuan yang luar biasa, namun perempuan tetap tidak memiliki tempat yang baik dalam kehidupan sosial. Hampir $70 \%$ (tujuh puluh persen) kasus kemiskinan di dunia dialami oleh perempuan $^{5}$ dan kepentingan perempuan kurang terwakili di lembaga-lembaga demokratis secara global, selain itu perempuan hanya menempatkan kurang dari 10\% (sepuluh persen) perwakilan parlemen dari sepertiga negara di dunia ${ }^{6}$, oleh karena itu penting untuk mengadopsi konsep keadilan gender pada sistem hukum, karena hukum memiliki fungsi sebagai a tool of social and bereucratic engineering, yang mengedepankan konsep panutan dan keteladanan ${ }^{7}$ bagi siapa saja untuk memperlakukan perempuan secara layak dalam kehidupan sosial. Keadilan gender hanya dapat terwujud dengan menerapkan suatu tipe hukum yang bersifat responsif.

Tipe hukum responsif mengakui adanya pluralisme hukum. Salah satu dampak pluralisme hukum adalah luasnya kesempatan untuk berpartisipasi dalam proses pembuatan hukum. Dengan cara ini, wilayah hukum masuk ke dalam dimensi politik, dimana partisipasi adalah summum bonum pada pembentukan instrumen hukum. Dengan kata lain, partisipasi menjadi kendaraan bagi sekelompok orang atau organisasi untuk ikut dalam mempengaruhi bentuk dan cara hukum bekerja. Aspek penting dari partisipasi terhadap perempuan adalah bahwa hukum yang akan dihasilkan merupakan representasi dari kepentingan dan kebutuhan subjektivitas perempuan.

Urgensi partisipasi dalam pembuatan hukum sebagaimana yang dikembangkan oleh Wilson tentang bagaimana penalaran perempuan dan laki-laki dalam hal pembuatan hukum mengenai aborsi. Bagi Wilson, laki-laki cenderung menggunakan pendekatan hukum tradisional dengan mengedepankan cara berfikir yang konvensional, abstrak, objektif, dan legalistik, maka hukum yang dihasilkan tidak akan efektif, karena laki-laki tidak memahami masalah yang dihadapi oleh perempuan dalam masa kehamilan, sehingga hukum yang dihasilkan berada di luar ranah pengalaman pribadinya. Hukum yang demikian tidak akan pernah menyelesaikan pada pokok permasalahan, oleh karena itu Wilson menganjurkan bahwa pembuatan hukum khususnya tentang aborsi harus melibatkan pengalaman perempuan. Pembuatan hukum yang mengatur mengenai aborsi memiliki konsekuensi psikologis, ekonomi, dan sosial yang mendalam bagi perempuan. Bagi Wilson, elemen-elemen dari jiwa perempuan berada dalam

5 World Hunger, tersedia di website https://www.worldhunger.org/women-and-hunger-facts/, diakses pada tanggal 15 Mei 2020.

6 UN Women, tersedia di website https://www.unwomen.org/en/what-we-do/leadership-and-politicalparticipation/facts-and-figures, diakses pada tanggal 15 Mei 2020.

7 Hatta Isnaini Wahyu, Penegakan Hukum dalam Perspektif Law as a Tool of Social Engineering dan Bereucratic Engineering, Jurnal IImu Hukum Justice Pro, Vol. 5, No. 1, Juni 2018, hlm 18. 
jantung permasalahan, sehingga hukum hanya akan efektif jika dibentuk dengan melibatkan perempuan. Wilson memaparkan bahwa setiap hukum yang dibentuk berdasarkan pengalaman perempuan adalah istimewa, karena perempuan memahami dirinya sendiri dan hubungannya dengan lingkungan sosial ${ }^{8}$.

Upaya meningkatkan partisipasi perempuan dalam pembuatan hukum merupakan wacana kontemporer dalam rangka mewujudkan keadilan gender melalui cara pemberdayaan perempuan (women empowerment) dalam ranah hukum. Sangat sulit mendefiniskan apa yang dimaksud dengan pemberdayaan, tetapi perlu digaris bawahi bahwa pemberdayaan perempuan dalam pengambilan keputusan hukum misalnya terkait penyelesaian konflik dan kekerasan terhadap perempuan dapat digambarkan sebaga sebuah zero-sum atau kekuatan yang menciptakan hubungan seperti cinta, penghormatan persahabatan sesama manusia, legitimasi dan lain sebagainya. Rawland memahami proses pemberdayaan perempuan dalam hukum adalah sebuah kesadaraan untuk menanamkan kekuatan dalam pengambilan keputusan dari berbagai bentuk dan kepentingan yang berbeda. Kekuatan yang dimaksud seperti kekuatan untuk mengontrol kekuatan itu sendiri, kekuatan generatif dan produktif yang menciptakan suatu keadaan dan kemungkinan tanpa dominasi, kekuatan untuk menumbuhkan kesadaran kelompok guna menyelesaikan masalah bersama, dan kekuatan spiritual yang tercipta dari keunikan masing-masing manusia, sebagai dasar penerimaan diri dan untuk menghargai penerimaan terhadap orang lain secara setara.

Kaum feminis menafsirkan kekuatan yang mencakup pemahaman akan dinamika penindasan yang terinternalisasi, sehingga menekankan pada penerapan pemberdayaan perempuan yang lebih dari sekedar partisipasi perempuan dalam pembuatan hukum, tetapi juga mencakup bahwa perempuan merasa mampu dan berhak untuk membuat keputusan hukum secara pribadi. Pemberdayaan perempuan secara radikal harus melibatkan kehancuran terhadap konstruksi hukum yang bersifat menindas, sehingga perempuan datang untuk melihat diri mereka memiliki kapasitas dan hak untuk bertindak dalam rangka mempengaruhi, membentuk, dan mengubah hukum.

Dari perspektif feminis tersebut, maka pemberdayaan adalah sebagai upaya untuk pengoperasian terhadap 3 (tiga) dimensi, yaitu dimensi pribadi yang mengembangkan kepercayaan diri dan kapasitas individu untuk menghancurkan penindasan dari hukum, dimensi rasional yang mengembangkan kemampuan bernegosiasi dan mempengaruhi sifat sesuatu

8 Bruce Anderson, 1996, Discovery In Legal Decision-Making, Dordrecht, Kluwer Academic Publishers, $\mathrm{hlm} 76$. 
hubungan dari keputusan hukum, dan dimensi kolektif yang menitikberatkan keterlibatan dalam struktur politik yang mencakup tindakan kolektif berdasarkan kerjasama daripada kompetensi ${ }^{9}$.

Feminis menjelaskan bahwa pemberdayaan yang dapat menempatkan kendali dan partisipasi perempuan merupakan sesuatu yang sangat penting dalam pengambilan keputusan hukum. Pengambilan keputusan hukum tersebut haruslah dilakukan melalui gender lens, yang berarti bahwa pemberdayaan perempuan dalam pengambilan keputusan hukum harus memenuhi beberapa kriteria, yaitu; perempuan memiliki kontrol atau mendapatkan kontrol lebih lanjut terhadap pembuatan keputusan hukum, perempuan memiliki suara yang didengarkan dalam pembuatan keputusan hukum, perempuan dapat mendefinisikan dan membuat perspektifnya untuk mempengaruhi pilihan sosial dalam keputusan untuk mempengaruhi bekerjanya hukum di dalam masyarakat, dan perempuan dihormati dan dihargai sebagai warga negara yang sederajat dalam memberikan kontribusi dalam pembangunan hukum pada suatu negara. Dengan demikian, pemberdayaan terhadap perempuan dalam pembuatan keputusan hukum adalah sebuah multifaceted process dengan melibatkan 4 (empat) aspek yang bersifat pararel, yaitu aspek ekonomi yang di dalamnya terdapat sumber daya perempuan, aspek publik atau politik yang memungkinkan bagi masyarakat untuk terlibat dalam pengambilan keputusan hukum, aspek struktur keluarga beserta kekuatan dan keterbatasan yang bersifat memaksa, dan yang paling penting adalah aspek psikologis yang dikembangkan melalui ideological sense tentang peran perempuan di masyarakat, yang kemudian membentuk persepsi dirinya sendiri tentang opsi-opsi yang memungkinkannya untuk dipertimbangkan.

Pemberdayaan perempuan dalam pembuatan hukum dengan menempatkan kendali dan partisipasi perempuan untuk mempengaruhi dan membentuk keputusan hukum memiliki tujuan untuk menjamin terpenuhinya kepentingan dan kebutuhan subjektivitas perempuan sebagai individu atau sebagai anggota kelompok suatu masyarakat yang berbeda secara usia, etnis, jenis kelamin maupun lokasi yang kemudian harus direpresentasikan melalui keputusan hukum, untuk menjamin terpenuhinya keadilan gender. Dengan terwujudnya keadilan gender tersebut, maka akan menghapus segala bentuk diskriminasi terhadap perempuan dalam bidang hukum. Dengan demikian, setiap keputusan hukum akan selalu mencerminkan prioritas bagi perempuan dari kebijakan negara dengan sistem dan proses yang lebih mencerminkan kepentingan perempuan dengan menyediakan ruang bagi suara perempuan yang merupakan bentuk komitmen gender dalam bidang hukum.

Bentuk aktualisasi komitmen gender dalam bidang hukum untuk mewujudkan keadilan gender bagi perempuan, salah satunya adalah dengan memasukkan konsep affirmative action

9 Aminur Rahman, Women's Epowerment: Concept and Beyond, Global Journal of Human Social Science Sociology \& Culture, Vol. 13, Issue 6, 2013, hlm 10. 
dalam penyelenggaraan keuangan daerah dengan partisipasi perempuan sebagai syarat utama dari setiap penyelenggaraan kebijakan keuangan daerah. Affirmative action atau tindakan khusus sementara yang dillaksanakan dalam rangka meningkatkan pengaruh perempuan dalam pengambilan kebijakan, sehingga menghasilkan kebijakan keuangan daerah yang merepresentasikan kebutuhan subjektivitas perempuan, salah satunya dengan mewujudkan kebijakan keuangan daerah untuk mempermudah aksestabilitas perempuan terhadap kredit lunak bagi Usaha Mikro Kecil dan Menengah (UMKM).

\section{Upaya Mewujudkan Reformasi Hukum di Indonesia Melalui Pendekatan Feminist Jurisprudence}

Sudikno Mertokusumo menyatakan bahwa sistem hukum adalah suatu kesatuan yang terdiri dari unsur-unsur yuridis seperti peraturan hukum, asas hukum, dan pengertian hukum yang mempunyai interaksi satu sama lain dan bekerja sama untuk mencapai tujuan kesatuan tersebut $^{10}$. Dalam perjalanan panjang, ternyata sistem hukum tidak pernah steril terhadap anasir-anasir metayuridisch, sebaimana yang dikatakan oleh Hans Kelsen bahwa metayuridisch adalah kaidah-kaidah di luar kasusnorm ${ }^{11}$ yang mempengaruhi bentuk dan tujuan dari sistem hukum tersebut. Pernyataan ini senada dengan Teori Sibernetika dari Talcot Parson, bahwa kehidupan masyarakat terutama kehidupan dalam berhukum, selalu dipengaruhi oleh subsistem lain, seperti budaya, ekonomi maupun politik ${ }^{12}$.

Hukum yang 'terkontaminasi' terhadap berbagai subsistem di luarnya memiliki pengaruh yang sangat luas terhadap kehidupan hukum, terutama kaitannya dengan pengaturan mengenai hak dan kewajiban laki-laki dan perempuan. Kuatnya sistem politik patriarki menyebabkan perempuan selalu tersingkirkan dalam sistem hukum nasional. Fenomena ini senada dengan pendapat Gumplowics, bahwa hukum selalu berdasarkan atas penaklukan yang lemah oleh yang kuat dan hukum adalah susunan definisi yang dibentuk oleh pihak yang kuat untuk mempertahankan kekuasaannya ${ }^{13}$. Lebih dari pada itu, adanya stereotip gender yang memberikan kategori luas sekaligus merefleksikan kesan dan keyakinan tentang apa perilaku yang tepat untuk laki-laki dan perempuan. Sebagai contoh, seorang perempuan dianggap memiliki kondisi fisik yang "kecil-mungil", sifat yang lembut dan pemikiran yang penuh intuisi, sebaliknya laki-laki dianggap memiliki kondisi fisik yang kuat, sifatnya pemberani dan

10 Sudikno Mertokusumo, 1991, Mengenal Hukum (Suatu Pengantar), Yogyakarta, Penerbit Liberty, hlm 102.

11 Mohammad Koesnoe, 2010, Dasar dan Metode Ilmu Hukum Positif, Surabaya, Airlangga University Press, hlm 40.

12 Aan Aswari, Sibernetiks, Teknologi Siber dan Kebutuhan Masyarakat, Lentora Justice, Vol 3, No. 2, 2016, hlm 44

13 Mirza Nasution, 2015, Politik Hukum dan Sistem Ketatanegaraan, Jakarta, Puspantara, hlm 1. 
pemikiran yang mengutamakan logika dalam menyelesaikan masalah. Penerimaan realitas hubungan antara laki-laki dan perempuan dalam mitos-mitos seperti itu adalah realitas yang terkristal dan diterima seperti seolah-olah benar oleh masyarakat, padahal sejatinya tidak pernah ada ${ }^{14}$. Dengan adanya stereotip ini, menyebabkan terjadinya pembagian peran yang diskriminatif terhadap perempuan, dimana perempuan dianggap selayaknya berperan dalam ranah domestik, sedangkan laki-laki selayaknya bekerja dalam ranah publik, sehingga stereotip yang demikian apabila diintegrasikan ke dalam norma hukum, maka akan menyebabkan hukum tersebut cacat dan diskriminatif.

Apabila dikatakan bahwa hukum itu cacat, maka penyebab cacat tersebut karena manusia merumuskan sebuah substansi dan ide ke dalam kalimat, kata-kata atau bahasa yang hanya didasarkan sebuah nilai tertentu yang bersifat diskriminatif ke dalam instrumen hukum. Setiap kali pembuat hukum berusaha merumuskan ide yang ada ke dalam instrumen hukum, maka setiap kali pula perempuan harus berhadapan dengan instrumen dan penegakan hukum yang diskriminatif. Selalu ada bagian, unsur, dan ciri yang tercecer dan tidak terumuskan dengan baik dan utuh melalui kata-kata itu, oleh karenanya reformasi hukum merupakan tujuan utama dari para penganut feminist jurisprudence guna mencapai hukum yang yang berkeadilan bagi perempuan ${ }^{15}$.

Feminist jurisprudence adalah aliran filsafat hukum yang berdasarkan pada kepercayaan atas kesetaraan politik, ekonomi, dan sosial berbasis gender ${ }^{16}$. Sebagai sebuah kajian dalam ilmu hukum, feminist jurisprudence mulai eksis pada tahun 1960-an. Feminist jurisprudence memegang peran penting dalam bidang ilmu hukum atas pemikirannya yang mempengaruhi banyak perdebatan tentang kekerasan seksual dan domestik, ketidaksetaraan di tempat kerja, dan diskriminasi berbasis gender. Melalui berbagai pendekatan, kaum feminis telah mengidentifikasi komponen-komponen gender dan implikasi gender dari norma hukum dan implementasinya yang tampak netral, sehingga menyebabkan hukum yang mempengaruhi pekerjaan, perceraian, hak reproduksi, pemerkosaan, kekerasan dalam rumah tangga, dan pelecehan seksual semuanya telah merugikan perempuan sepanjang sejarah kehidupan manusia, sehingga harus direkonstruksi.

Kaum feminis percaya bahwa sejarah hukum ditulis dari sudut pandang laki-laki dan tidak mencerminkan peran perempuan dalam membuat sejarah dan menyusun tatanan masyarakat. Hukum yang demikian telah menghadirkan karakteristik laki-laki sebagai norma dan karaktristik

14 Aditya Yuli Sulistyawan, Feminist Legal Theory Dalam Telaah Paradigma: Suatu Pemetaan Filsafat Hukum, Jurnal Masalah-Masalah Hukum, Jilid 47, No. 1, Januari 2018, hlm 60.

15 Satjipto Rahardjo, 2009, Hukum dan Perilaku: Hidup Baik Adalah Dasar Hukum Yang Baik, Jakarta, Kompas Media Nusantara, hlm 4.

16 Neeuro Tandon, 2008, Feminism: A Paradigm Shift, New Delhi, Atlantic Publishers \& Distributors, hlm 123. 
perempuan sebagai penyimpangan dari norma, oleh karenannya hukum yang berlaku akan selalu memperkuat dan melanggengkan kekuasaan patriarki. Bagi kaum feminis, konsep gender diciptakan secara sosial, bukan secara biologis. Bagi kaum feminis, perbedaan biologis hanya menciptakaan perbedaan penampilan fisik dan kapasitas reproduksi, bukan menciptakan konstruksi psikologis, moral, atau sosial, sehingga tidak layak hukum yang akan diberlakukan, menempatkan perbedaan biologis sebagai dasar untuk melakukan pembedaan terhadap perempuan dan laki-laki dalam hal hubungannya dalam kehidupan bernegara.

Feminist jurisprudence mengkritisi hukum yang dibentuk berdasarkan nilai maskulin, karena hukum yang demikian menunjukkan sejumlah keterbatasan atau keterkaitan pada realitas nilai-nilai sosial yang bersifat menindas. Keterbatasan tersebut terkait kenyataan bahwa rumusan hukum adalah phallocentric (dominasi laki-laki), keterbatasan yang berkaitan dengan proses kerja dalam struktur hukum menjadi masalah bagi feminis dalam memperjuangkan hakhak perempuan, dan keterbatasan yang berkaitan dengan batasan pengadilan yang memfokuskan pada sesuatu yang hanya bersifat rasional dan logis (masuk akal) saja. Dengan demikian, reformasi hukum adalah cara terbaik untuk mencapai hukum yang berkeadilan bagi perempuan.

Reformasi hukum dalam mewujudkan keadilan bagi perempuan harus dilandasi dengan penelitian yang komprehensif. Proses reformasi hukum untuk mewujudkan keadilan, hendaknya menggunakan kajian yang multidisiplin, karena hukum dalam masyarakat selalu dipengaruhi oleh berbagai aspek lainnya, seperti kuantitas, ruang lingkup dan tempat, dinamika dan konstan, kekuatan berlakunya hukum, kausalitas, organisasi dan lembaga-lembaga, psikis seperti kehendak, akuntabilitas yuridis, konsesus, perbedaan, pertentangan, sejarah kekuasaan politik, ekonomi, pengaturan atau pembatasan kepentingan-kepentingan ekonomi, estetika misalnya harmoni, bahasa, hubungan hukum dan interaksi dalam masyarakat, pluralisme norma hukum dan norma lainnya, seperti moral, agama dan kepercayaan.

Reformasi hukum menurut feminist jurisprudence bertujuan untuk mengubah sejarah hukum yang secara terang-terangan mengecualikan perempuan dari kehidupan publik, misalnya perempuan tidak memiliki hak pilih dan perempuan yang sudah terikat dalam hubungan perkawinan tidak dapat memiliki hak atas properti. Seperti yang dikatakan oleh Margaret Davies, bahwa reformasi hukum yang diilhami oleh kaum feminis liberal dimulai dengan premis bahwa ada masalah ketidasetaraan yang terjadi dalam beberapa konteks. Pada tahun-tahun awal gerakan feminis liberal, diskriminasi tampaknya mengalir langsung kepada status hukum perempuan, sehinga reformasi hukum dipandang oleh beberapa pihak sebagai 
jalan yang cukup memberikan kesetaraan sosial dalam bidang hukum ${ }^{17}$. Argumentasi yang dikembangkan guna mencapai reformasi hukum yang berkeadilan, yaitu bahwa prosedur penerapan hukum adalah 'lelucon' dengan sistem hukum yang dibentuk adalah 'korup', maka keadilan tidak akan pernah menang selama tidak ada aturan yang istimewa bagi perempuan.

Feminist jurisprudence menekankan pada penggunaan data sosiologis dengan saran yang bersifat taktis dalam upaya reformasi hukum. Penggunaan data sosiologis sangat ditentang oleh penganut doktrin tradisional hukum, karena dianggap 'bukan benar-benar hukum'. Penggunaan data sosiologis pertama kali dalam upaya menganalisis fenomena hukum sebenarnya bukan dicetuskan oleh penganut feminist jurisprudence, tetapi oleh aliran lain, seperti sociological jurisprudence, namun data sosiologis yang digunakan memiliki perbedaan, karena feminist jurisprudence lebih menekankan pada persoalan data sosiologis tentang perempuan. Data sosiologis tentang perempuan adalah pusat metodologis feminis, yang berdasarkan pada penemuan, pembagian, dan analisis pengalaman konkret perempuan.

Data sosiologis akan mengungkapkan bahwa hukum di masa lalu hanya bertujuan untuk menetapkan stabilitas sosial dan hukum akan mengakar pada norma-norma penindasan, oleh karenanya reformasi menjadi sangat penting, karena hasil reformasi hukum bisa menjadi jangkar ke masa lalu atau mesin untuk masa depan. Setiap fungsi ini memiliki tempatnya masing-masing, sehingga feminist jurisprudence berupaya untuk memeriksa dan merumuskan bentuk reformasi yang ideal, agar tercipta doktrin hukum untuk mengatasi segala bentuk diskriminasi dan dominasi yang sudah mengakar dan memperkuat ketidakadilan pada masa lalu, karena dengan reformasi hukum melalui pendekatan feminist jurisprudence akan menghasilkan konsep hukum untuk membentuk institusi manusia yang adil pada masa sekarang dan masa yang akan datang.

Upaya melakukan reformasi terhadap sistem hukum dalam mewujudkan keadilan bagi perempuan, harus didasarkan atas beberapa beberapa pertimbangan, diantaranya tentang bagaimana perempuan dan laki-laki dapat memperoleh akses yang setara atas sumber daya yang akan diatur dalam peraturan perundang-undangan. Misalnya, akses terhadap fasilitas kesehatan, pengambilan keputusan pada saat melahirkan, akses terhadap informasi, pendidikan, dan sumber daya ekonomi. Perlu diperhatikan apakah peraturan perundangundangan memberikan kesempatan untuk berpartisipasi yang setara bagi perempuan dan lakilaki untuk melaksanakan hak dan kewajibannya dalam setiap kebijakan dan program pembangunan. Selanjutnya, perlu dilakukan analisis apakah norma hukum yang akan dirumuskan dalam peraturan perundang-undangan memuat ketentuan yang berkenaan dengan

17 Reg Graycar dan Jenny Morgan, Law Reform: What's In It For Women? Windsor Yearnook of Access to Justice, Vol 23, No 2, 2005, hlm 395. 
kontrol yang setara berkenaan dengan relasi antara laki-laki dan perempuan dalam pelaksanaan hak dan kewajiban. Selain itu, perlu dikritisi apakah norma hukum dalam peraturan perundang-undangan mampu menjamin suatu kebijakan dan program yang akan menghasilkan manfaat yang setara bagi laki-laki dan perempuan. Dengan mewujudkan reformasi hukum yang demikian, diharapkan dapat memberikan keadilan substantif bagi perempuan. Keadilan substantif dalam pembuatan hukum memberikan kewajiban bagi para perancang hukum dalam hal ini peraturan perundang-undangan untuk mengidentifikasikan persoalan perempuan dan menjadikannya sebagai persoalan yang representatif untuk diagendakan dalam proses pembuatan instrumen hukum. Dengan demikian hukum yang dibentuk harus beorientasi pada tujuan dan akibat bagi kemaslahatan hidup perempuan.

\section{Simpulan}

Berdasarkan uraian pembahasan di atas, maka dapat ditarik beberapa simpulan, antara lain:

1. Konsep hukum yang berkeadilan bagi perempuan, bahwa hukum harus menjamin perempuan untuk berhak hidup bermartabat dan bebas tanpa rasa takut, yang dapat terwujud dengan menerapkan tipe hukum responsif, karena tipe hukum responsif mengakui adanya pluralisme hukum. Salah satu dampak pluralisme hukum adalah luasnya kesempatan bagi perempuan untuk berpartisipasi dalam proses pembuatan hukum. Upaya mewujudkan partisipasi perempuan dalam pembuatan hukum dilakukan dengan menerapkan konsep pemberdayaan perempuan (women empowerment). Pemberdayaan lebih dari sekedar persoalan partisipasi tetapi juga mencakup bahwa perempuan merasa mampu dan berhak untuk membuat keputusan hukum secara pribadi. Pemberdayaan perempuan mencakup 3 (tiga) dimensi, yaitu dimensi pribadi, dimensi rasional, dan dimensi kolektif. Urgensi pemberdayaan perempuan dalam proses pembuatan hukum adalah hukum yang dihasilkan akan lebih efektif dan istimewa, karena perempuan lebih memahami dirinya sendiri serta hubungannya dengan lingkungan sosial.

2. Upaya mewujudkan reformasi hukum melalui pendekatan feminist jurisprudence, dimulai dengan persepsi bahwa hukum yang dibentuk berdasarkan nilai maskulin menunjukkan sejumlah keterbatasan atau keterkaitan pada realitas nilai-nilai sosial yang bersifat menindas. Argumentasi yang dikembangkan guna mencapai reformasi hukum yang berkeadilan, yaitu bahwa prosedur penerapan hukum adalah 'lelucon' dengan sistem hukum yang dibentuk adalah 'korup', maka keadilan tidak akan pernah menang selama tidak ada aturan yang istimewa bagi perempuan, sehingga hukum yang demikian harus dilakukan reformasi, guna mencapai keadilan bagi perempuan. Feminist jurisprudence 
menekankan penggunaan data sosiologis tentang perempuan sebagai landasan reformasi hukum. Data sosiologis tentang perempuan adalah pusat metodologis feminis, yang berdasarkan pada penemuan, pembagian, dan analisis pengalaman konkret perempuan. Selain itu, reformasi hukum juga harus didasarkan atas pertimbangan tentang apakah peraturan perundang-undangan yang ada memberikan akses, partisipasi, kontrol, dan manfaat bagi perempuan dari pembentukan suatu instrumen hukum yang mempengaruhinya, sehingga hukum yang dihasilkan dapat mewujudkan keadilan substantif bagi perempuan.

\section{DAFTAR PUSTAKA}

\section{Buku:}

Anderson Bruce, 1996, Discovery In Legal Decision-Making, Dordrecht, Kluwer Academic Publishers.

Koesnoe Mohammad 2010, Dasar dan Metode Ilmu Hukum Positif, Surabaya, Airlangga University Press.

Mertokusumo Sudikno, 1991, Mengenal Hukum (Suatu Pengantar), Yogyakarta, Penerbit Liberty.

Nasution Mirza, 2015, Politik Hukum dan Sistem Ketatanegaraan, Jakarta, Puspantara.

Rahardjo Satjipto, 2009, Hukum dan Perilaku: Hidup Baik Adalah Dasar Hukum Yang Baik, Jakarta, Kompas Media Nusantara.

Tandon Neeuro, 2008, Feminism: A Paradigm Shift, New Delhi, Atlantic Publishers \& Distributors.

Widanti Agnes, 2005, Hukum Berkeadilan Gender:Aksi Interaksi Kelompok Buruh Perempuan dalam Perubahan Sosial, Jakarta, Penerbit Buku Kompas.

\section{Jurnal:}

Aditya Yuli Sulistyawan, Feminist Legal Theory Dalam Telaah Paradigma: Suatu Pemetaan Filsafat Hukum, Jurnal Masalah-Masalah Hukum, Jilid 47, No. 1, Januari 2018.

Aan Aswari, Sibernetiks, Teknologi Siber dan Kebutuhan Masyarakat, Lentora Justice, Vol 3, No. 2, 2016.

Aminur Rahman, Women's Epowerment: Concept and Beyond, Global Journal of Human Social Science Sociology \& Culture, Vol. 13, Issue 6, 2013.

Hatta Isnaini Wahyu, Penegakan Hukum dalam Perspektif Law as a Tool of Social Engineering dan Bereucratic Engineering, Jurnal IImu Hukum Justice Pro, Vol. 5, No. 1, Juni 2018.

Ica Wulansari, Dominasi Maskulin versus Kesetaraan Gender, Jurnal Mozaik, Vol. 13, No. 1, Januari-Juni 2013. 
Muhaimin, Penerapan Asas Oportunitas oleh Kejaksaan Agung Bertentangan dengan Asas Legalitas dan Rule of Law, Jurnal Penelitian Hukum De Jure, Vol. 17, No. 1, Maret 2017.

Reg Graycar dan Jenny Morgan, Law Reform: What's In It For Women? Windsor Yearnook of Access to Justice, Vol 23, No 2, 2005.

Wahyuni Retnowulandari, Budaya Hukum Patriarki versus Feminis: Dalam Penegakan Hukum Di persidangan Kasus Kekerasan Terhadap Perempuan, Jurnal Hukum, Vol. 8, No. 3, Januari 2010.

\section{Website:}

UN Women, tersedia di website https://www.unwomen.org/en/what-we-do/leadership-andpolitical-participation/facts-and-figures, diakses pada tanggal 15 Mei 2020.

World Hunger, tersedia di website https://www.worldhunger.org/women-and-hunger-facts/, diakses pada tanggal 15 Mei 2020. 